\title{
Moldes contrários: o romantismo como modelo (negativo) para o naturalismo
}

\author{
Negative models: the romanticism as a (negative) model to the \\ naturalism
}

\author{
Alan Victor Flor da SILVA ${ }^{1}$ \\ (Universidade Federal do Pará) \\ Germana Maria Araújo SALES ${ }^{2}$ \\ (Universidade Federal do Pará)
}

\begin{abstract}
RESUMO: Modelos negativos são paradigmas com os quais não desejamos ser comparados, aos quais queremos nos contrapor ou dos quais esperamos ser diferentes. Considerando-se, portanto, esse conceito, a partir dos romances O Mulato (1881), de Aluísio de Azevedo, A Normalista (1893), de Adolfo Caminha, e Hortência (1888), de Marques de Carvalho, objetivamos, com este trabalho, demonstrar que os idealizadores do Naturalismo no Brasil atribuem ao Romantismo, ainda que de forma negativa, a função de modelo. Para tanto, este estudo terá como foco principal as personagens femininas Ana Rosa, Maria do Carmo e Hortência, pois essas mulheres da ficção naturalista apresentam um perfil acentuadamente romântico e, consequentemente, são estigmatizadas e recebem um final que não condiz com o qual desejam. Essa perspectiva de análise contrapõe-se à ideia de alguns historiadores da literatura brasileira, como Lúcia Miguel Pereira e Nelson Werneck Sodré, que afirmam que o Naturalismo, ainda que disfarçado com cenas realistas, permaneceu na essência romântico.
\end{abstract}

PALAVRAS-CHAVE: Modelo negativo. Romance. Personagens femininas. Naturalismo. Romantismo.

ABSTRACT: Negative models are paradigms that we do not want to be compared to, to which we either want to oppose or we want to be different. Analyzing, therefore, this concept, using the novels $O$ Mulato (1881), by Aluísio de Azevedo, A Normalista (1893), by Adolfo Caminha, and Hortência (1888), by Marques de Carvalho, we intend, with this article, to show that the creators of Naturalism in Brazil impute to Romanticism, though in negative way, a model. Therefore, this article will focus on the main central female characters Ana Rosa, Maria do Carmo and Hortência, because these female naturalist characters evidence a extremely romantic profile and, consequently, they are stigmatized and ends the novel's story inconsonant to their wishes. This analysis perspective opposes the idea of some historians of Brazilian literature, as Lúcia Miguel Pereira and Nelson Werneck Sodré, who claim that naturalism, albeit disguised in realistic scenes, remained in romantic essence.

KEYWORDS: Negative models. Novel. Female characters. Naturalism. Romanticism.

\section{CONSIDERAÇÕES INICIAIS}

Os romancistas naturalistas sempre criticaram o Romantismo, pois já o julgavam saturado nas últimas décadas do século XIX e, por essa razão, sempre se contrapuseram radicalmente a

\footnotetext{
1 Aluno de doutorado do Programa de Pós-graduação em Letras da UFPA. Atua na linha de pesquisa: Literatura: interpretação, circulação e recepção. E-mail: alan.flor@hotmail.com

2 Professora Associada da Faculdade de Letras do Instituto de Letras e Comunicação e do Programa de PósGraduação em Letras, da UFPA. Doutora em Teoria e História Literária pela UNICAMP. Coordena o Programa de Pós-Graduação em Letras da UFPA e preside a Associação Brasileira de Literatura Comparada (gestão 2014-2015). E-mail: gmaa.sales@gmail.com
}

(C) Revista Moara, n.41, jan.-jun. 2014, Estudos Literários. ISSN 2358-0658 (Impresso).

Programa de Pós-Graduação em Letras / Universidade Federal do Pará. Todos os direitos reservados 
ele. Nesse sentido, podemos afirmar que o movimento romântico serviu como modelo negativo para os adeptos do Naturalismo, que não apenas era um movimento pós-romântico, como também antirromântico.

Segundo José Luís Jobim (2012), quando atribuímos a um movimento literário qualquer a função de modelo, não podemos nunca perder de vista que ele pode ser tanto positivo quanto negativo. Modelos negativos são paradigmas com os quais não desejamos ser comparados, aos quais queremos nos contrapor ou dos quais esperamos ser diferentes, muito embora continuem nos sendo modelos. Desse modo, se quisermos marcar nossa diferença em relação a um modelo negativo, não podemos esquecer que ele continua sendo nosso referente, ainda que almejemos evitá-lo, confrontá-lo, não repeti-lo ou talvez até mesmo satirizá-lo.

A partir, portanto, dos romances $O$ Mulato (1881), de Aluísio de Azevedo, A Normalista (1893), de Adolfo Caminha, e Hortência (1888), de Marques de Carvalho, objetivamos, com este trabalho, demonstrar que os idealizadores do movimento naturalista no Brasil atribuem ao movimento romântico, ainda que de forma negativa, a função de modelo. Para tanto, este estudo terá como foco as personagens femininas centrais das três obras já citadas. Primeiramente, porque essas personagens são apresentadas como excessivamente românticas e, por essa razão, tornam-se vítimas fáceis da própria idealização que criam a respeito do amor. Em segundo lugar, porque, conforme Marisa Lajolo e Regina Zilberman (1999), há uma idealização da figura feminina em romances românticos, que se contrapõe ao modo como as mulheres viviam na sociedade brasileira oitocentista, pois as mulheres da ficção, ao contrário, são mais prendadas, perspicazes e boas leitoras.

\footnotetext{
Examinada desde a perspectiva dos escritores românticos, não é assim tão irremediável, grave, precária e culturalmente insatisfatória - como se poderia crer, a partir da leitura de viajantes e cronistas - a condição da leitura feminina. Em contos, romances e poemas, passeiam moças finamente educadas, sobretudo quando pertencem à classe superior. (LAJOLO; ZILBERMAN, 1999, p. 248)
}

Emília, de Diva (1864), Lúcia, de Luciola (1862), e Aurélia, de Senhora (1875), obras de José de Alencar; Dionísia, de Uma paixão romântica (1869), obra de Joaquim Manoel de Macedo, Guiomar, de $A$ mão e a luva (1874), romance de Machado de Assis; são exemplos de personagens femininas da ficção brasileira romântica que são sofisticadas, bem educadas, virtuosas e boas leituras, sobretudo de Shakespeare e Chateaubriand.

Nos romances naturalistas, no entanto, a figura da mulher já é mais estigmatizada, pois as personagens femininas são representadas como ingênuas leitoras de romances frívolos, além de verdadeiras tolas românticas, sonhadoras, inconsequentes, histéricas e exageradamente sentimentais.

Objetivamos evidenciar, portanto, que Ana Rosa, Maria do Carmo e Hortência, respectivamente personagens femininas das obras $O$ Mulato, A Normalista e Hortência, são personagens veementemente românticas e, por essa razão, são condenadas e recebem um final que não condiz com o qual desejam.

\section{O NATURALISMO SOB ACUSAÇÃO}

Desde seu surgimento até os dias de hoje, o Naturalismo foi relegado pela crítica a um lugar periférico no âmbito da História da Literatura Brasileira (MENDES, 2006). Foram várias as acusações destinadas aos romances naturalistas, cujo julgamento, quase sempre desfavorável, partiu da pena de críticos atualmente consagrados, como José Veríssimo (1978), Lúcia Miguel 
Pereira (1988) e Nelson Werneck Sodré (2002). Entre as censuras às quais o Naturalismo foi submetido, elencamos a seguir as mais recorrentes:

- Descrição minuciosa de cenas de obscenidades no enredo das obras (literatura torpe ou pornográfica);

- Reprodução fiel ou má assimilação do modelo naturalista francês (sobretudo a respeito de Émile Zola);

- Inexpressão de temas locais ou de peculiaridades do Brasil que garantissem a nacionalidade da literatura brasileira;

- Ausência de verossimilhança e de densidade literária na economia dos romances;

- Atraso acentuado em relação à manifestação do Naturalismo na Europa;

- Continuidade do Romantismo, apenas disfarçado com cenas realistas;

- Falsificação da arte.

Em meio a tantas críticas, os escritores naturalistas, em geral, se utilizavam de suportes para materializar um discurso em defesa do movimento ao qual se vincularam, como os jornais e os prefácios de suas próprias obras. Júlio Ribeiro, por exemplo, escreveu o próprio prólogo de seu romance $A$ Carne, publicado pela primeira vez em 1888. Elaborado em forma epistolar e em língua francesa, o prefácio de seu romance foi destinado a Émile Zola, considerado o precursor e a figura mais expressiva da estética literária naturalista. Nesse pequeno preâmbulo, Júlio Ribeiro afirma que os escritores adeptos do Naturalismo no Brasil não pretendem imitar os passos de Émile Zola. Na verdade, o que sentem pelo escritor francês é apenas uma grande admiração.

Eu não sou temerário, eu não tenho a pretensão de seguir seus passos. Nós não pretendemos seguir seus passos para escrever um pobre estudo por pouco que seja naturalista. Nós não o imitamos, nós o admiramos. (RIBEIRO, 1972, p. 21, tradução nossa $)^{3}$

No pequeno prólogo do romance Hortência, publicado pela primeira vez em 1888, Marques de Carvalho demonstra-se intolerante em relação aos presumíveis julgamentos aos quais estaria sujeito, escritos pelos "mesquinhos mercenários do baixo jornalismo", que não compreenderiam o projeto literário de seu trabalho recém-lançado, moldado a partir das máximas naturalistas.

Este livro despretensioso salta hoje para a rua, desafiando os botes agarotados de todos os meus detratores. Os insultos da hipocrisia literária que não gosta de ver-se descrita e combatida nos livros de pura e severa naturalidade intransigente .Mais uma vez direi: não me intimidam as banalidades que, a seu respeito, hão de lançar-me os mesquinhos mercenários do baixo jornalismo: tenho para mim que as insídias de semelhante corja devem servir-me de poderoso incentivo para novos trabalhos. Só é discutido o homem de merecimento. Aí está toda a minha vingança. (CARVALHO, 1997, p. 9)

\footnotetext{
${ }^{3}$ No original: “Je ne suis pas téméraire, je n'ai pas la prétention de suivre vos traces; ce n'est pas prétendre suivre vos traces que d'écrire une pauvre étude tant soit peu naturaliste. On ne vous imite pas, on vous admire."
} 
Embora assevere que as críticas que seriam destinadas a seu romance lhe seriam improdutivas, Marques de Carvalho acredita que os julgamentos triviais dos quais seria alvo the serviriam apenas de incentivo a novos trabalhos, pois, segundo o escritor paraense, somente os homens de merecimento são dignos de comentário.

É possível perceber, portanto, que, no final do século XIX, havia um debate efervescente acerca do mais novo movimento literário anti- e pós-romântico. De um lado, havia os defensores, os próprios romancistas, que se esforçavam para defender e promover o Naturalismo no Brasil. Do outro, havia os detratores, os críticos literários, que não desculparam as obscenidades e a linguagem considerada inadequada nas obras de cunho naturalista, além de outras acusações que depreciaram e continuam depreciando o romance naturalista brasileiro.

Diante de inúmeras denúncias, um aspecto abordado pela crítica literária que desqualifica o romance naturalista chama-nos muito a atenção: a continuidade do Romantismo, apenas disfarçado com cenas realistas. Lúcia Miguel Pereira (1988), por exemplo, afirma que os romancistas naturalistas apresentavam um espírito romântico e apenas disfarçaram com realismo o romantismo que ainda cultivavam em si mesmos.

\begin{abstract}
E a melhor prova de que o naturalismo nos foi imposto pela moda está em ter sido tão mal assimilado. Praticaram-no sempre como quem executa uma receita os nossos romancistas, que, no espírito, continuavam românticos: não há disso prova mais expressiva do que $O$ Mulato, que representou a vitória da nova escola, tendo, entretanto, apenas disfarçado com cenas realistas o seu romantismo. (PEREIRA, 1988, p. 122)
\end{abstract}

Além de Lúcia Miguel Pereira, Nelson Werneck Sodré (2002) afiança que o Naturalismo no Brasil não significou, de fato, uma ruptura com o Romantismo, pois este ainda continuou sua existência, ainda que reformulado a partir de outros aspectos.

\begin{abstract}
O naturalismo, pelo menos considerado em seus moldes clássicos, não teve uma longa duração no Brasil, e nem mesmo correspondeu a um rompimento pronunciado com as formulações românticas. Continuou o romantismo a sua existência, embora sobre outras formas, e o próprio naturalismo não ficou imune ao mágico e fascinante filtro romântico. (SODRÉ, 2002, p. 425)
\end{abstract}

É curioso, no entanto, que Lúcia Miguel Pereira e Nelson Werneck Sodré tenham afirmado que o Romantismo continuou sua existência no Brasil, pois os escritores naturalistas brasileiros sempre se contrapuseram radicalmente a ele, pois acreditavam que esse movimento literário, em pleno final do século XIX, já se encontrava saturado. No prefácio do romance em folhetim $O$ pajé, publicado no jornal $A$ República, Marques de Carvalho, por exemplo, afirma que se desvinculou da estética romântica para escrever um romance que seguisse os princípios naturalistas:

\footnotetext{
Desejei fazer um romance que fosse simplesmente um estudo físico-psicológico desse personagem astucioso e hipócrita que é o terror dos espíritos fanáticos do povo de minha província; para isso, alienei-me da velha escola romântica, desprezei-lhe os abusos e prolixidades, para deixar-me levar pela grande orientação literária da nossa época. (CARVALHO, 1887, p. 3)
} 
Nesse prefácio, o escritor paraense, assim como muitos outros romancistas naturalistas no Brasil, denuncia os abusos e as prolixidades da escola romântica e investe no Naturalismo, que se apresentava, no final do século XIX, como a mais nova e promissora orientação literária do momento.

Considerando, portanto, o prefácio do romance $O$ pajé, podemos observar que o Naturalismo contrapõe-se fortemente ao Romantismo. Como é possível, então, que os romancistas naturalistas tenham continuado, no espírito, românticos? Para compreendermos a fundo o modo como o Naturalismo foi pensado no século XIX, recorreremos a Émile Zola, que não apenas escreveu obras ficcionais de cunho naturalista, como também elaborou as máximas do romance experimental. Logo no primeiro parágrafo do artigo Do romance, Zola (1995) assegura que a imaginação e a fantasia não são mais qualidades que podem ser atribuídas aos novos romances.

O mais belo elogio que se podia fazer a um romancista outrora era dizer: "Ele tem imaginação". Hoje, esse elogio seria visto quase como uma crítica. É que todas as condições do romance mudaram. A imaginação já não é a qualidade mestra do romancista. (ZOLA, 1995, p. 23)

Embora Zola admita que a imaginação seja um artifício utilizado até mesmo pelos escritores que se detêm a produzir romances naturalistas, qualidade sem a qual não seria possível escrever uma obra ficcional, esse estratagema deve ser ocultado sob o real.

\begin{abstract}
Com o romance naturalista, o romance de observação e de análise, as condições mudam imediatamente. O romancista inventa ainda mais; inventa um plano, um drama; apenas, é uma ponta de drama, a primeira história surgida, e que a vida cotidiana sempre lhe fornece. Em seguida, na estruturação da obra, isso tem bem pouca importância. Os fatos só estão lá como desenvolvimentos lógicos das personagens. O grande negócio é colocar em pé criaturas vivas, representando diante dos leitores a comédia humana com a maior naturalidade possível. Todos os esforços do escritor tendem a ocultar o imaginário sob o real. (ZOLA, 1995, p. 24)
\end{abstract}

Assim, para que o real se sobreponha ao imaginário, Zola informa que, para compor uma obra de cunho naturalista, quase todos os escritores contemporâneos precisam tomar longas notas, examinar todas as fontes e adquirir todos os documentos que lhe sejam necessários. Somente após essa investigação é que é possível para os romancistas começar a escrever, pois, segundo Zola, a configuração da obra origina-se de forma natural, lógica e espontânea justamente a partir dessa pesquisa na qual os escritores se devem se deter.

Quase todos estabelecem suas obras a partir de notas, tomadas longamente. Quando estudaram com um cuidado escrupuloso o terreno onde devem caminhar, quando se informaram em todas as fontes e têm em mãos os múltiplos documentos dos quais necessitam, somente nesse momento decidem-se a escrever. O plano da obra lhes é trazido por esses próprios documentos, pois acontece de os fatos se originarem logicamente, este antes daquele; estabelece-se uma simetria, a história se compõe de todas as observações recolhidas, de todas as notas tomadas, uma puxando a outra, pelo próprio encadeamento da vida das personagens, e a conclusão nada mais é que uma consequência natural e inevitável. Vê-se, nesse trabalho, o quanto o imaginário tem pouca importância. (ZOLA, 1995, p. 24-25) 
Além de desqualificar a imaginação como elemento imprescindível para compor a economia do romance, Zola defende que o senso do real é o principal atributo de um escritor. Para o autor francês, no entanto, essa qualidade, embora pareça intrínseca a todo o ser humano dotado de razão, é muito rara, pois o homem, de modo geral, observa os fatos da vida a partir de sua visão muito particular e, por esse motivo, não consegue perceber a realidade tal qual ela é. Nesse sentido, o senso do real pode ser visto como uma disposição natural ou um dom com o qual o ser humano nasce.

\begin{abstract}
O senso do real é sentir a natureza e representá-la tal qual ela é. Parece, inicialmente, que todo mundo possui dois olhos para ver e que nada deve ser mais comum do que o senso do real. Entretanto, nada é mais raro. Os pintores sabem muito bem disso. Coloquem alguns pintores diante da natureza, eles a verão do modo mais barroco do mundo. Cada um a perceberá sob uma cor dominante; um a fará tender ao amarelo, um outro ao violeta, um terceiro ao verde. Para as formas, os mesmos fenômenos se produzirão; um arredonda os objetos, outro multiplica os ângulos. Cada olho tem, assim, uma visão particular. Enfim, há olhos que não veem absolutamente nada. Possuem sem dúvida alguma lesão, o nervo que os liga ao cérebro sofre de uma paralisia que a ciência ainda não pode determinar. O certo é que de nada adiantará observarem a vida se mover ao seu redor, jamais saberão reproduzir exatamente uma cena. (ZOLA, 1995, p. 26)
\end{abstract}

Em seu famoso artigo O romance experimental, Zola (1982) também demonstra como não apenas a realidade, mas também a verdade são elementos essenciais para a economia do romance naturalista. Se, para o romancista francês, a realidade é ponto de partida e só pode ser captada a partir de uma observação atenta e minuciosa dos fatos, a verdade é o produto final ao qual o escritor deve buscar com base na experiência.

\footnotetext{
O romancista é feito de um observador e de um experimentador. Nele, o observador apresenta os fatos tal qual os observou, define o ponto de partida, estabelece o terreno sólido no qual as personagens vão andar e os fenômenos a se desenvolver. Depois, o experimentador surge e instituí a experiência, quer dizer, faz as personagens evoluírem numa história particular, para mostrar que a sucessão dos fatos será tal qual a exige o determinismo dos fenômenos estudados. [...] O romancista sai em busca de uma verdade. (ZOLA, 1982, p. 31)
}

Além do senso do real, outro aspecto da crítica de Zola está relacionado a uma das máximas do romance experimental: o indivíduo é determinado pelo ambiente e pela hereditariedade (ZOLA, 1982). Baseando-se na observação fiel da realidade e na experiência, o romancista deve mostrar a relação recíproca entre o homem e a sociedade, de tal modo que o meio externo (o social), associado também ao meio interno (o fisiológico), exerce sobre ele uma influência constante. Do mesmo modo, esse mesmo homem que é produto do meio social e ainda dos próprios aspectos biológicos produz e modifica todos os dias o meio em que vive. Nesse sentido, a sociedade e o indivíduo estabelecem uma relação de interdependência, de tal modo que dentro de um mesmo sistema um age e reage sobre o outro.

As máximas do romance experimental - a rejeição à imaginação, o senso do real e o determinismo pelo meio interno e externo - foram muito caras não apenas a Émile Zola, como 
também aos escritores brasileiros, pois o romance naturalista, segundo os textos críticos de Zola, é mais um estudo do comportamento humano do que necessariamente uma obra de cunho ficcional. O romancista, para chegar ao produto final, que é o romance, precisa, antes de tudo, ser um observador atento para perceber a tese na qual pretende deter-se. Nesse sentido, podemos afirmar que o escritor é mais um cientista do que um romancista propriamente dito.

Considerando, portanto, que os escritores naturalistas brasileiros conheciam as máximas do romance experimental, propostas por Émile Zola em seus textos de crítica literária, podemos afirmar que a permanência do romantismo em obras escritas à maneira zolista não se sustenta, uma vez que o Naturalismo foi idealizado como uma forma de contrapor-se ao movimento estético-literário anterior.

\section{O ROMANTISMO COMO MODELO NEGATIVO}

Os escritores naturalistas, de um modo geral, embora procurassem demonstrar que romperam completamente seus laços com o Romantismo, não deixaram de considerar os princípios românticos como modelo negativo para a construção de suas narrativas. Os romancistas defensores do movimento naturalista, por exemplo, ridicularizaram ou banalizaram personagens estereotipicamente românticas dentro de suas narrativas, principalmente as femininas. Da passagem do Romantismo para o Naturalismo, a mulher, figura antes idealizada e considerada anjo da pureza e da perfeição, passa a ser representada no romance não apenas como uma criatura virtuosa, mas também como uma personagem que comporta defeitos antes inimagináveis a um ser do sexo feminino. Assim, as mulheres da ficção naturalista, quando são caracterizadas à luz da idealização romântica, são ridicularizadas, pois são consideradas impróprias ao mais novo movimento estético-literário.

No romance $O$ Mulato, de Aluísio de Azevedo, Ana Rosa é uma personagem acentuadamente romântica, pois não apenas sonha com um belo noivado e com um lindo casamento, como também idealiza um marido com qualidades imensuráveis: forte, corajoso, bonito, talentoso, apaixonado e formoso, capaz de tudo para merecê-la como mulher e como esposa.

\footnotetext{
Agora, só o que lhe convinha era um marido! O seu, o verdadeiro, o legal! O homem da sua casa, o dono do seu corpo, a quem ela pudesse amar abertamente como amante e obedecer em segredo como escrava. Precisava de dar-se e dedicar-se a alguém; sentia absoluta necessidade de pôr em ação a competência, que ela em si reconhecia, para tomar conta de uma casa e educar muitos filhos.Com estes devaneios, acudia-lhe sempre um arrepiozinho de febre; ficava excitada, idealizando um homem forte, corajoso, com um bonito talento, e capaz de matar-se por ela. E, nos seus sonhos agitados, debuxava-se um vulto confuso, mas encantador, que galgava precipícios, para chegar onde ela estava e merecer-lhe a ventura de um sorriso, uma doce esperança de casamento. E sonhava o noivado: um banquete esplêndido! e junto dela, ao alcance de seus lábios, um mancebo apaixonado e formoso, um conjunto de força, graça e ternura, que a seus pés ardia de impaciência e devorava-a com o olhar em fogo. (AZEVEDO, 1991, p. 20-21)
}

Nesse excerto, parece que o narrador ironiza os sentimentos e os desejos mais íntimos de Ana Rosa, em vez de enaltecê-los e exaltá-los de forma sublime, contrariamente ao que ocorre nos romances românticos. $\mathrm{O}$ narrador aluisiano descreve os anseios pessoais da personagem por 
um homem idealizado de um modo acentuadamente exagerado e em tom mordaz, banalizandoos e satirizando-os, por conseguinte.

Muito embora, em O romance experimental, Émile Zola (1982) defenda que o escritor deve ser um observador, apresentando, portanto, os fatos na ficção do mesmo modo como foram observados na vida real (o que significa, por conseguinte, uma ausência total de juízo de valor), observamos no romance $O$ Mulato que Ana Rosa é censurada por comportar-se como uma personagem estereotipicamente romântica, pois o narrador acentua sarcasticamente seus devaneios, suas pretensões e seus sentimentos.

Além disso, o narrador não deixa de insinuar que Ana Rosa já amava alguém que ainda nem mesmo conhecia. Esse fato implica que a personagem valorizava mais o amor e o sentimento do que o ser amado, o homem que merecesse sua estima e sua devoção.

\footnotetext{
Mas o noivo por onde andava que não vinha? Esse belo mancebo, tão ardente e tão apaixonado, por que se não apresentava logo? Dos homens que Ana Rosa conhecia na província nenhum decerto podia ser!... E, no entanto, ela amava...

A quem?

Não sabia dizê-lo, mas amava. Sim! Fosse a quem fosse, ela amava; porque sentia vibrar-lhe todo o corpo, fibra por fibra, pensando nesse - Alguém - íntimo e desconhecido para ela; esse - Alguém - que não vinha e não lhe saía do pensamento; esse - Alguém - cuja ausência a fazia infeliz e lhe enchia a existência de lágrimas. (AZEVEDO, 1991, p. 21)
}

Quando o jovem e distinto Raimundo chega à cidade de São Luís do Maranhão, Ana Rosa enxerga na figura do próprio primo a possibilidade de amar e de ser amada, cuja realização apenas não foi possível porque o rapaz era mulato e, por essa razão, a família opôs-se radicalmente a essa união. Após a morte do homem que Ana Rosa amava perdidamente, a menina casa-se, ao final do romance, com o antirromântico Luís Dias, o responsável pela morte de Raimundo.

\footnotetext{
O par festejado eram o Dias e Ana Rosa, casados havia quatro anos. Ele deixara crescer o bigode e aprumara-se todo; tinha até certo emproamento ricaço e um ar satisfeito e alinhado de quem espera por qualquer vapor o hábito da Rosa; a mulher engordara um pouco em demasia, mas ainda estava boa, bem torneada, com a pele limpa e a carne esperta. Ia toda se saracoteando, muito preocupada em apanhar a cauda do seu vestido, e pensando, naturalmente, nos seus três filhinhos, que ficaram em casa a dormir.

- Grand'chaine, double, serré! berravam nas salas.

O Dias tomara o seu chapéu no corredor e, ao embarcar no carro, que esperava pelos dois lá embaixo, Ana Rosa levantara-lhe carinhosamente a gola da casaca.

- Agasalha bem o pescoço, Lulu! Ainda ontem tossiste tanto à noite, queridinho!... (AZEVEDO, 1991, p. 190)
}

Notamos, ao final do romance, que era mais importante para Ana Rosa estar amando do que o ser amado. Luís Dias tinha, antes de casar com a filha de seu patrão e benfeitor, uma fisionomia repugnante e um caráter reprovável para ser o herói de um romance romântico, mas, após a morte de seu concorrente e seu aprumo, tornou-se o homem ideal para quem Ana Rosa pudesse doar-se e devotar-se. A ironia final do romance, portanto, não se refere somente ao fato de que a idealização romântica foi vencida por forças antagônicas, bem à maneira naturalista. A figura feminina também foi satirizada, pois Ana Rosa é a personagem mais romântica da obra e 
foi apresentada como ingênua e vítima de sua própria idealização a respeito do amor, deixando-se dominar por seus anseios mais íntimos e por seus sentimentos idealistas.

Assim como Ana Rosa, Maria do Carmo, personagem feminina central do romance $A$ Normalista, de Adolfo Caminha, é exageradamente romântica, pois sonhava em casar-se com o jovem requintado e afortunado José de Souza Nunes, conhecido por todos pelo apelido de Zuza.

\begin{abstract}
Maria, a um canto do sofá, pensava no estudante, perdida num labirinto de reflexões, com uma languidez no olhar vago. O Zuza preocupava-a como um sonho de ouro. Começava a sentir o que nunca sentira por homem algum, certo desejo de ter um marido a quem pudesse entregar-se de corpo e alma, certa sentimentalidade sem causa positiva, uma como abstração do resto da humanidade. E quando D. Amélia, sentandose ao piano, começou a tocar a Juanita, veio-lhe um vago e esquisito desejo de ir-se pelo mundo afora nos braços do "seu" Zuza, rodopiando numa valsa entontecedora até cansar... Via-se nos braços dele, arquejando ao compasso da música, quase sem tocar o chão, voando quase leve como um floco de algodão, como uma pena, como uma coisa ideal e aérea... E lembrava-se do padrinho. Ah! o padrinho queria tanto mal ao Zuza... Doravante ia agradar muito a João, tratá-lo com mais carinho, dar-lhe muitos cafunés, fazer-lhe todas as vontades, adulá-lo, a fim de que ele não ralhasse por causa do estudante. Que tola não ter escrito $\operatorname{logo}$ ao Zuza, àquele Zuza que era agora a quantidade constante de seus cálculos, a preocupação única de seu espírito, o seu alter ego! (CAMINHA, 1973, p. 64)
\end{abstract}

O homem por quem a normalista estava apaixonada, porém, não a idealiza como uma personagem feminina de um romance romântico, que apresenta qualidades inestimáveis. Embora tenha declarado por meio de uma carta seu amor à jovem Maria do Carmo, Zuza, em meio a seus pensamentos, revela todas as suas impressões negativas acerca da normalista:

Depois lhe veio à mente a normalista, a cearense do Trilho de Ferro. Muito bonitinha, é verdade, mas uma tola que não sabia tratar com rapazes educados. Lá por ser pobre não; mas parecia-lhe tão atrasadinha, assim como apalermada, indiferente a tudo. Além disso, um nome de matuta Maria do Carmo. Ainda se fosse Maria Luíza, mas Maria do Carmo!...

Começou então a fazer considerações sobre Maria. Achava-a até parecida com a Francina, uma rapariga de Pernambuco, também morena e de olhos cor de azeitona, baixinha e sem vergonha, "passada" por todos os estudantes de academia. Mas mesmo muito parecida, agora é que se lembrava: era a Francina. Um horror! No Ceará não se encontravam mulheres públicas de certa ordem. Tudo era uma récua de meretrizes imundas, carregadas de sífilis até aos olhos. Os rapazes viviam se queixando de moléstias secretas. (CAMINHA, 1973, p. 96)

Além de considerá-la boba e ingênua, Zuza compara Maria do Carmo fisicamente a uma meretriz que se chamava Francina. Essa comparação demonstra ainda mais o quanto o bacharel em direito tem uma visão negativa acerca da normalista. É por essa razão que Zuza revela-se um verdadeiro personagem antirromântico, uma vez que não idealiza a figura de Maria do Carmo nem estava disposto a sacrificar sua posição social e seu futuro promissor para casar-se como uma mulher de origem humilde, como ilustra a citação a seguir: 
- Ora sabem que mais? Há males que vêm para bem. A cidade está cheia do meu nome e do nome da rapariga, o verdadeiro é ir-me embora mesmo, sem dar satisfação a ninguém. Meu pai é um homem de juízo. Eu podia muito bem engraçar-me deveras com a menina para casar e depois... sabe Deus as consequências. Já se foi o tempo de um homem sacrificar posição e futuro por uma mulher pobre. Concluo o meu curso e sigo para a Europa, é o verdadeiro, ora adeus! (CAMINHA, 1973, p. 68)

Para o bacharel em direito, Maria do Carmo, embora seja uma rapariga muito bonita, élhe muito inferior para unir-se a ela em matrimônio, não apenas em razão de sua condição social, mas também por causa de sua falta de elegância, de astúcia e de altivez. Além disso, o personagem Zuza afirma, em uma das passagens do romance, que as cartas de amor que Maria do Carmo lhe havia enviado serviriam para despertar o riso em seus amigos pernambucanos.

E assim, uma a uma, o futuro bacharel releu toda a série de cartas da normalista, enfeixando-as depois, dobradinhas, com um cadarço.

Que horror, meu Deus, quanta banalidade! E ela a tomar a coisa a sério! A gente sempre faz asneiras de criança nessa idade!...

E guardando o maço de cartas no fundo da maleta: "- Magnífico rol de asneiras para fazer rir a rapaziada de Pernambuco”. (CAMINHA, 1973, p. 171)

Para evidenciar ainda mais o menosprezo que Zuza sente por Maria do Carmo, o bacharel em direito, já a bordo do vapor que lhe levaria do Ceará para Pernambuco, afirma que, se havia algo que lhe prendia àquele lugar, era unicamente a figura de sua mãe - d. Sofia. Desse modo, observamos que a normalista não teve uma representação significativa na vida de Zuza, uma vez que os laços maternos eram o único motivo que lhe proporcionava um sentimento de pertença ao Ceará.

\footnotetext{
Através da confusão que reinava no seu espírito, como um ponto luminoso por entre um nevoeiro denso, via mentalmente e nitidamente a cabeça branca de d. Sofia, de sua mãe, e só então sentiu que uma coisa prendia-lhe ao Ceará, atraía-lhe a essa terra que ele tanto detestava. Não sabia mesmo por que, por índole, por sistema, por pedantismo. - Sim, queria mal ao Ceará, mas não podia esquecer nunca o Ceará, porque nele ficava a sua velha que ainda há pouco, abraçando-o entre lágrimas, metera-lhe no bolso uma nota de cem mil-réis e cheirando a fundo de baú. (CAMINHA, 1973, p.173-174)
}

O perfil antirromântico do personagem Zuza revela-se também em razão de seu caráter narcisista, pois o bacharel em direito tem consciência de que é um bom partido para qualquer mulher que lhe desperte algum interesse.

De repente: - "E a normalista que não lhe tinha respondido a carta!" Muito atrasadinhas as cearenses, pensava. Que mais queria ela? E defronte do espelho, pondo a gravata: - "Era uma rapaz chique, dava muita honra à sra. d. Maria do Carmo escrevendo-lhe uma carta amorosa, pois não? Era o que lhe faltava a sra. d. Maria do Carmo não lhe dar atenção! Mas havia de cair por força. Era uma questão de tempo." (CAMINHA, 1973, p. 98) 
Assim, notamos que, enquanto o narrador do romance $O$ Mulato sugere uma satirização do romantismo de Ana Rosa, ao descrever com um tom sarcástico e com um exagero acentuado os ensejos e os sentimentos dessa personagem feminina, o narrador do romance $A$ Normalista demonstra direta e nitidamente como Maria do Carmo é uma personagem romântica e, por essa razão, torna-se vítima fácil dos comentários ferrenhos, não apenas da sociedade de Fortaleza, como também de Zuza, homem com o qual a rapariga gostaria de casar-se.

Além disso, em razão de sua própria ingenuidade e ignorância, características atribuídas pelos escritores naturalistas às personagens mais de acordo com o estereótipo romântico, o final de Maria do Carmo no romance é trágico. A normalista, além de não se casar com o jovem Zuza, é possuída sexualmente por João da Mata, seu padrinho.

Do mesmo modo como Ana Rosa e Maria do Carmo, Hortência, personagem principal do romance homônimo de Marques de Carvalho, enquadra-se no grupo das personagens românticas representadas de maneira estereotipada em romances naturalistas. Embora não fosse uma mulher ávida pela leitura de romances, pois mal sabia ler e escrever, era tão romântica como as outras aqui apresentadas.

Hortência tinha consciência de que vivia em um meio favorável à libertinagem e aos vícios e, em razão dos conselhos da mãe e de uma professora que lhe ensinara as primeiras letras, ainda se conserva pura e almejava entregar-se apenas ao homem que a amasse e que estivesse disposto a desposá-la.

\begin{abstract}
A simples rapariga tinha horror ao homem, à junção carnal dos corpos, por temperamento, por instinto, conhecendo já todos os segredos dos sexos, em resultado da liberdade completa em que fora criada e do meio em que tinha vivido. Repugnandolhe as crapulosas pândegas desonestas de todas as pessoas de sua classe, havia sabido conservar-se pura, inteiramente imaculada de corpo e de espírito, reservando com escrúpulo a sua pessoa para entregá-la um dia ao homem a quem amasse, e que resolvesse tomá-la por mulher. (CARVALHO, 1997, p. 48)
\end{abstract}

Por mais que desejasse manter-se casta, Hortência foi vítima dos desejos libidinosos do próprio irmão Lourenço, um vadio consumado e voluptuoso. No entanto, apesar de ter sido deflorada, percebemos no decorrer do romance que a personagem feminina central apaixona-se pelo homem que violou sua castidade.

Antes de ser possuída sexualmente, a mulata não aprovava o estilo de vida desregrada que o irmão levava. Entretanto, depois de tornar-se enfermeira da Santa Casa de Misericórdia, Hortência e a mãe foram convidadas por Lourenço para ir ao circo de cavalinhos. Nesse dia, a mulata passou a enxergar o irmão com outros olhos.

Esquecia-se da vida real, de todas as tristes cenas da sua existência na Santa Casa, para lançar-se no seio do inesperado divertimento que lhe proporcionara o irmão. Um sentimento de gratidão ergueu-se-lhe no espírito para com Lourenço. Levantou os olhos, cravou-os no rosto do rapaz. Achou-o simpático, bonito quase, diferente do que lhe tinha parecido até ali, pela influência da predisposição otimista em que se achava. Contemplou-o longamente, amoravelmente, analisando-lhe com vagar e insistência as linhas todas do semblante, combinando traços e traços, feições com feições, estranhamente, como se tentasse, num esforço atlético do espírito obediente à vontade, cravar nos refolhos da alma a fisionomia do irmão. Era um renascimento completo no seu modo de encarar Lourenço. Sentia-se complacente, disposta a esquecer as tolices do doidivanas, com a necessidade de perdoar tudo, na largueza incomparável do seu bondoso coração. (CARVALHO, 1997, p. 76) 
É possível observar que Hortência põe mais em evidência os traços físicos do que o gesto generoso de Lourenço, de tal modo que o mulato parece ter sido valorizado pela jovem enfermeira mais por sua figura masculina do que por sua figura fraterna. Essa nova visão que Hortência passou a ter de Lourenço demonstra, portanto, que a mulata já tinha uma predisposição para enamorar-se pelo próprio irmão.

No dia em que manteve relações sexuais com Lourenço pela primeira vez, Hortência demonstra uma ingenuidade por não saber bem ao certo os verdadeiros interesses e caprichos do irmão, como ilustra o excerto a seguir.

\footnotetext{
Hortência, assustada, não compreendia perfeitamente aquela rápida ternura do irmão. Achava-lhe no rosto uma expressão estranha: atribuiu-a, sem medo, à dolorosa ação do incômodo que o tinha acometido. E só muito tarde, quando não mais podia fugir, teve a completa percepção de tudo, no momento em que o irmão, de salto, abraçando-a atleticamente, num esforço violento e bestial, ergueu-a a meia altura do solo, beijando-a doidamente, e rolou com ela para o fundo da rede, ansioso, ofegante, as cordoveias salientes, belo de alegria, sublime de virilidade vitoriosa. (CARVALHO, 1997, p. 82)
}

Hortência, contudo, já conhecia "todos os segredos dos sexos, em resultado da liberdade completa em que fora criada e do meio em que tinha vivido" (CARVALHO, 1997, p. 48). É por essa razão que a ingenuidade da jovem enfermeira deve ser encarada, senão como uma dissimulação, pelo menos minimamente com certo receio. Além disso, para corroborar que a mulata não manteve relações sexuais com Lourenço a contragosto, Hortência não demonstra ter nenhum tipo de resistência aos anseios e às investidas do irmão.

Após o primeiro ato sexual, Hortência reflete muito a respeito do que lhe aconteceu e das consequências que a ação do irmão poderia lhe trazer. Porém, paradoxalmente, ao mesmo tempo em que dele sente raiva, a mulata tenta justificar a proeza de Lourenço. Primeiramente, acredita que deve perdoá-lo por ser difícil resistir à beleza de suas formas tão estonteantes.

O arrojo do irmão tomava agora umas certas proporções de heroísmo amoroso, feito em homenagem à beleza triunfal das suas irrepreensíveis formas tentadoras. Desculpava-o por isso, com uma benignidade doce no fundo negro dos grandes olhos vivos. (CARVALHO, 1997, p. 84)

Em seguida, Hortência defende que se sentia orgulhosa por finalmente considerar-se uma mulher de verdade e por não ignorar mais os segredos do sexo. Além disso, tenta conceber o sexo como um ato natural, praticado por todos os homens, independentemente da classe social.

\footnotetext{
Além disso, uma espécie de orgulho invadia-a - com o fresco da noite quase fechada por ter, finalmente, passado pela imolação natural do seu sexo utilizado. E então? Que tal? Era uma verdadeira mulher, completa, sem defeitos, sem ignorar nada! E alegravase com semelhantes ponderações, reconstruindo na mente a cena da véspera, na tranquilidade noturna do seu pequenino quarto de virgem. Fizera acaso algum mal? Pois aquilo não estava a dar-se por aí todos os dias, em presença do mundo indiferente? E ela - sim ela - como tinha sido criada, se não daquele modo? E o irmão, e mãe e toda a gente? O mundo era aquilo: a constante empresa da reprodução das espécies
} 
funcionando em todas as engrenagens das camadas sociais. A sorte era onipotente. A sua sina era aquela: conformar-se-ia. (CARVALHO, 1997, p. 85)

Finalmente, a enfermeira consolava-se por ter perdido a virgindade com o irmão, alguém que a apreciava, em vez de entregá-la a um homem qualquer, que se vangloriasse depois pelo êxito de seu ato infame.

A enfermeira deixou-se apoderar de uma tristeza doce e tranquila ao rodeá-la a escuridade. Era desgraçada agora, sem a sua virgindade, mas consolava-se, todavia, porque a perdera com um irmão que a estimava, em vez de dá-la totalmente a qualquer vagabundo das estradas, que fizesse alarde da sangrenta vitória... (CARVALHO, 1997, p. 86)

Após a segunda vez em que se envolveu sexualmente com o irmão, percebemos que Hortência conforma-se com o que o destino lhe reservara.

\begin{abstract}
A rapariga sentia-se mal disposta, com uma pontinha de náusea remexendo-lhe o estômago, revoltada pelos excessos viris daquele insaciável macho que ali estava diante dela, a conversar naturalmente, olhando-a sem segundo-sentido, contando à mãe o que observara na mata e dando-lhe, a tal respeito, as impressões próprias com uma tranquilidade satisfeita de homem saciado de gozo, feliz no abastecimento. Passavamlhe pela mente, ainda atônita, as peripécias do dia, no Marco da Légua. E insensivelmente admirava-se do arrojo de Lourenço, da sua constância, da pertinência com que a desejara e solicitara até conseguir possuí-la de novo, em pleno ar, como as bestas-feras no cio, rolando pelo chão em paroxismos do gozo requintado. Não havia como fugir ao destino, representado naquele homem fatal, que sobre ela começava a exercer tão salientada preponderância. A sua sorte já estava traçada, com certeza, pelo poder que regula todos os movimentos humanos, independentemente da vontade. A sua superstição levantava-se mais uma vez cheia de força, vitoriosa e enervante, a darlhe uma compreensão piegas e desfalecida do futuro. Não poderia fugir ao domínio dessa força sobrenatural, que ela previa irresistível, a dispor livremente da sua existência. Que fazer? Havia de resignar-se a tudo, numa passividade de inconsciente, obedecendo à disposição celestial da divindade. Agora, que a possuíra novamente o irmão, entregar-se-ia a ele, sem forças para reagir, perseguida como estava pelo pavor do incognoscível, da misteriosa superstição fanática e boçal que a empolgava toda inteira, aprisionando-lhe o entendimento e a vontade. Fizesse o que Deus mandasse! (CARVALHO, 1997, p. 115-116)
\end{abstract}

Além da figura de homem no vigor de sua virilidade, é possível apreender que Lourenço, metaforicamente, pode ser concebido pela irmã como uma criatura divina - "Havia de resignar-se a tudo, numa passividade de inconsciente, obedecendo à disposição celestial da divindade" (grifo nosso) -, uma vez que a obediência de Hortência pode ser referida tanto a Deus quanto ao próprio irmão.

Lourenço, por conseguinte, passa a ser visto por Hortência como uma figura paradoxal, porque o homem que foi capaz de deflorá-la é o mesmo que ela estava amando. A entrega da personagem feminina ao destino que lhe aguardava, portanto, não deve ser compreendido apenas como um conformismo ou como uma fatalidade, mas também como uma aceitação dos próprios desejos e do amor que Hortência sentia pelo irmão. Nesse sentido, a última frase da citação Fizesse o que Deus mandasse! (grifo nosso) - é ambígua. Assim como pode estar se referindo a 
uma entidade divina e celestial, Hortência pode estar também fazendo alusão a Lourenço, o homem de sua vida, a quem jurou submissão e doação.

A jovem mulata entregou-se e doou-se ao homem que amou: "Daquele domingo em diante começou uma vida nova para ambos. Amaram-se e procuraram-se como dois esposos." (CARVALHO, 1997, p. 116). Porém, em razão do perfil desregrado de Lourenço, os momentos felizes não duraram muito tempo entre os dois, pois Hortência sofreu muito com as violências, as traições e as beberagens do irmão, responsável também por assassiná-la friamente ao final do enredo. Pode ser considerado, portanto, o romantismo de Hortência a causa não apenas de seu envolvimento com o próprio irmão numa relação incestuosa, como também a razão de seu final trágico no desfecho do romance.

\section{CONSIDERAÇÕES FINAIS}

Ao finalizar a (re)leitura dessas obras, concluímos que Ana Rosa, Maria do Carmo e Hortência são personagens femininas de romances naturalistas com o estereotipo romântico. A psicologia de cada uma demonstra uma idealização do amor, do sentimentalismo e do homem que escolheram para amar. Essas qualidades são consideradas por romancistas naturalistas como fortemente exageradas e, por essa razão, essas três personagens são estigmatizadas e satirizadas, além de receberem um final que não condiz com aquele que desejam. Nesse sentido, a suposta continuidade do Romantismo - como assim afirmam Lúcia Miguel Pereira e Nelson Werneck Sodré - não passa de uma ideia equivocada a respeito do modo como os romancistas naturalistas representaram certos aspectos do movimento literário anterior.

Ridicularizar personagens com o estereótipo romântico, principalmente as femininas, evidencia que os escritores naturalistas brasileiros, como Aluísio de Azevedo, Adolfo Caminha e Marques de Carvalho, concebiam que os ideais do Romantismo não poderiam ser mais seguidos e, por conseguinte, contrapuseram-se a eles radicalmente. É por essa razão que a ideia de quebra, de rompimento e de ruptura em relação aos paradigmas românticos aparece com frequência no discurso dos defensores do Naturalismo no Brasil, como, por exemplo, nos prefácios de seus romances ou em artigos jornalísticos.

Entretanto, esses autores, embora quisessem cortar qualquer tipo de vínculo com o movimento literário anterior, precisaram conhecer os ideais românticos para serem capazes de contestá-los e, consequentemente, satirizá-los em suas obras. Nesse sentido, atribuir ao Romantismo a condição de modelo para o Naturalismo, por mais que seja de forma negativa, não é uma ideia equivocada, pois os modelos podem ser tanto positivos quanto negativos.

\section{REFERÊNCIAS}

AZEVEDO, Aluísio de. O Mulato. São Paulo: Ática, 1991.

CAMINHA, Adolfo. A Normalista. Rio de Janeiro: Editora Três, 1973.

CARVALHO, Marques de. Hortência. Belém: Cejup: Secult, 1997.

O pajé. A República, Belém, 18 jan. 1887, p. 3. 
JOBIM, José Luís. O passado na história literária: modos de ver. Manuscrito. Rio de Janeiro, 2012.

LAJOLO, Marisa; ZILBERMAN, Regina. A formação da leitura no Brasil. São Paulo: Ática, 1999.

MENDES, Leonardo Pinto. As qualidades da incorreção: o romance naturalista no Brasil. In: MELLO, Celina Maria Moreira de; CATHARINA, Pedro Paulo Garcia Ferreira (Orgs.). Crítica e movimentos do campo literário: configurações discursivas do campo literário. Rio de Janeiro: 7 Letras, 2006.

PEREIRA, Lúcia Miguel. História da literatura brasileira: prosa de ficção (de 1870 a 1920). Belo Horizonte: Itatiaia; São Paulo: Editora da Universidade de São Paulo, 1988.

RIBEIRO, Júlio. A Carne. Rio de Janeiro: Editora Três, 1972.

ROMERO, Sílvio. A literatura em perspectiva. In: CANDIDO, Antonio (Org.). Sílvio Romero: teoria, crítica e história literária. Rio de Janeiro: Livros Técnicos e Científicos; São Paulo: EDUSP, 1978.

SODRÉ, Nelson Werneck. História da literatura brasileira. 10. ed. Rio de Janeiro: Graphia, 2002.

VERÍSSIMO, José. O romance naturalista no Brasil. In: BARBOSA, João Alexandre (Org.). José Veríssimo: teoria, crítica e história literária. Rio de Janeiro: Livros Técnicos e Científicos; São Paulo: EDUSP, 1978.

ZOLA, Émile. Do romance: Stendhal, Flaubert e os Goncourt. Trad. Plínio Augusto Coelho. São Paulo: Imaginário; Editora da Universidade de São Paulo, 1995.

O romance experimental. In: O romance experimental e o Naturalismo no teatro. São Paulo: Perspectiva, 1982.

Recebido em 31/03/2013.

Aprovado em 12/08/2013. 